\title{
Responsible I(m)ovation in Asia Pacific regions
}

\author{
Veronica Scuotto ${ }^{1,2}$ (D) - Alexeis Garcia-Perez ${ }^{3}$. David E. Kalisz ${ }^{4}$. \\ Amandeep Dhir ${ }^{5,6,7}$
}

Accepted: 4 January 2022

(c) The Author(s) 2022

\begin{abstract}
Over the past 20 years, a debate has developed on the differences between innovation and imitation strategies as mechanisms by which businesses operating in the Asia Pacific region may gain a competitive advantage. The current research contributes to this debate from a different perspective by exploring some of the challenges and opportunities associated with the combination of both strategies into what has been defined as imovation. Imovators and imovations do not stand alone in business ecosystems. Rather, they should be embraced in the context of sustainability-related virtues and emerging capabilities, such as ethical behaviour, co-responsibility and positive social impact. Taking dynamic capabilities as a theoretical lens, this paper conducts an empirical investigation of responsible imovation in a sample of 180 enterprises operating in the Asia Pacific market. In particular, this research evaluates the relationship between dynamic capabilities and imovation capabilities using a logistic regression analysis whereby we correlate the three main features of imovation strategies: strategic alliances, strategic decision-making and product innovations. To the best of our knowledge, ours is the first study to focus on responsible imovation in the Asia Pacific market from an empirical perspective. The research highlights the key organisational and individual actions with the potential both to preserve existing capabilities and to create and integrate new ones. Our findings highlight the importance of technology adoption for responsible imovation to become more effective and accessible to imovators in the Asia Pacific business ecosystem. We conclude that responsible imovations combined with product-level innovations and core dynamic capabilities pave the way towards more rapid growth and a more sustainable competitive advantage.
\end{abstract}

Keywords Responsible imovation - Asia Pacific region · Dynamic capabilities · Innovation $\cdot$ Imitation

Veronica Scuotto

veronica.scuotto@unina.it

Extended author information available on the last page of the article

Published online: 11 January 2022 


\section{Introduction}

The evolution and disruptive nature of innovation in firms operating in the Asia Pacific region have been the focus of an increasing volume of research in recent years (Lu et al., 2008; Su et al., 2009; Zhu et al., 2012; Yi et al., 2017; Wang et al., 2019; Zhao et al., 2020). However, another growing body of literature suggests that imitation capabilities in the region are evolving more quickly than the ability of firms to innovate (Jahanshahi \& Brem, 2020; Wu et al., 2019; Bloodgood, 2019; Luo et al., 2011). Paradoxically, only a few scholars have discussed the intertwining of the two strategies-innovation and imitation, which the relevant literature terms 'imovation' (Wu et al., 2020).

Imovators, defined as creative imitators (Scuotto \& Shukla, 2018; Luo et al., 2011), 'seek imitation opportunities and work to leverage and implement them to the benefit of the organisation' (Shenkar, 2010, p. 4). Imovators are agile and lean and can adapt quickly to changes in the market (Krzakiewicz \& Cyfert, 2016). They conduct large scale searches and integrate new knowledge by developing strategic alliances with other firms (Wang \& Scuotto, 2012). For example, the first action of the Lenovo Group was the acquisition of IBM's ThinkPad PC business, worth $\$ 1.75$ billion. Through this prominent equity strategic alliance, Lenovo acquired the 'Think' family of products, which is classified as the premium-brand leader in the global PC industry. The acquisition enabled Lenovo to catch up with IBM in terms of worldwide distribution, sale networks and advanced technologies (Deng 2007). Lenovo also surpassed IBM's managerial skills, increasing its own technological and innovative abilities by at least five years (Scuotto \& Shukla, 2018 , p. 219). As this example demonstrates, imovators are not focused on their own territory or a local business; rather, they look beyond their market to acquire small firms or firms positioned to fail (Shenkar, 2010) or to gain new technologies or potential capabilities (Shenkar, 2010; Scuotto \& Shukla, 2018; Wang \& Scuotto, 2012). Gradually, this topic is gaining attention from scholars who seek to understand the potential of innovation and imitation to generate sustainable outputs for society (Blok, 2018; Pandza \& Ellwood, 2013) and a sustainable competitive advantage for firms (Pérez-Luño et al., 2007; Wanasika \& Conner, 2011).

Following the publication of Barney's (1991) work on firm resources and sustained competitive advantage, several authors have considered innovation alone as the source of a sustainable competitive advantage because it could provide the firm with inimitable resources. Years later, authors such as Pérez-Luño et al. (2007) began asserting that imitation also allows firms to derive valuable and sustainable opportunities for a competitive advantage. With this in mind, the current research is now set to explore whether the combination of innovation and imitation can generate a sustainable competitive advantage for the firm or, even more importantly, whether such a combination can offer sustainable benefits for society. By adopting the concept of responsible innovation (Blok, 2018; Pandza \& Ellwood, 2013), we explore the concept of responsible imovation as a mix of responsible innovation and imitation strategies. The concept of responsible imovation relies on the virtues and emerging capabilities of individual ethical 
behaviour, co-responsibility and social impact (Pandza \& Ellwood, 2013). To the best of our knowledge, this is the first study to take dynamic capabilities as a theoretical lens and empirically investigate responsible imovation in a sample of 180 enterprises operating in the Asia Pacific market. In particular, this research evaluates the relationship between dynamic capabilities and imovation capabilities using a logistic regression analysis whereby we correlate the three main features of imovation strategies: strategic alliances, strategic decision-making and product innovations. We then explore the relationship between dynamic capabilities and responsible imovation. With this background, the article highlights the need for firms to preserve their existing capabilities and to integrate and create new ones while employing new technologies. We conclude that responsible imovation introduces a new sustainable way of merging innovation and imitation to increase a firm's competitiveness.

The remainder of this paper is organised as follows. The following sections provide theoretical background on the three main areas driving this research: innovation, imitation and responsible imovation, with a focus on the Asia Pacific region. Then the paper discusses the theoretical framework of dynamic capabilities, which enables us to develop our hypotheses. The methodology section justifies and details the empirical analysis, and a discussion of the results follows. The paper concludes with the theoretical and managerial implications as well as the limitations of the study and areas for future research.

\section{Theoretical background}

\section{Innovation, imitation and responsible imovation}

Over the past centuries, societies have transitioned from agrarian to industrial to knowledge economies. Each new wave has brought change and synthesis. During each transition, the previous economy remains in place but is affected by the new one as individuals and organisations interpret ideas and their outcomes from a fresh perspective, which produces myriad novel applications. Today, developments in information and communication technologies and their applications are paving the way for new, customer-centred business models, which are disrupting the way people live and work. Knowledge of the customer-resulting from the application of data analytics techniques - allows organisations to design and provide personalised products and services that often require only an information technology infrastructure. In this context, innovation is perceived as a viable strategy and an essential tool for organisations to achieve sustainable growth and profitability (Bonsu \& Kuofie, 2019).

Although the concept of innovation has existed since the dawn of mankind, over the last decades, it has been redefined in various ways, ranging from the novelty of a product (Pérez-Luño et al., 2007) to a product's adoption by a firm (Damanpour, 1991). From a process perspective, Schumpeter (1961) described innovation as a way to synthesise various capabilities and resources, whereas Thompson (1967) highlighted the 'novel' side of innovation when describing it as the process 
of generating, accepting and implementing an idea. Doloreux and Shearmur (2013, p. 723) argued that 'innovation is a collective process that, to be successful, requires the integration of complementary external knowledge in order to enhance the firm's knowledge base'. Other studies have similarly considered the impact of innovation on the 'world knowledge set' (Grossman \& Helpman, 1991; Mahmood \& Rufin, 2005), distinguishing firms oriented by science, entrepreneurship or market (Genc et al., 2019; Zou et al., 2018; Miller, 1983; Narver \& Slater, 1990). Unsurprisingly, most of the extant literature on the subject refers to innovation, innovators and innovative practices as the source of much of the current socio-economic growth (Ramoglou et al., 2020). Frenz and Lambert (2012) described innovation strategies as the purposeful implementation of innovation-oriented activities that are carried out together, in a systemic way, to create and market a new good or service or to improve production, delivery and business processes. Williamson and Yin (2014) found that recent innovation strategies in Chinese firms seek to cut the lead times for new product development by rapidly incorporating user feedback into new designs to reduce the learning curve and by restructuring their organisations to accelerate problem-solving. Their work underscores the role of knowledge from practice in the success of innovation strategies. In fact, Stankevice (2015) related highly successful innovation strategies to effective knowledge management practices, arguing that innovation types and innovation strategies are often defined through the lens of knowledge types. Stankevice (2015) further asserted that to design a unique input into its future innovation strategy, an enterprise requires a set of knowledge activities that it can apply, integrate, re-engineer, etc.

Despite the range of perspectives on the concept of innovation and related strategies, one area in the extant literature is particularly relevant for the purpose of our research. The role of knowledge and knowledge-intensive business services in innovation has the potential to inform our study of imovation in the context of the knowledge economy. Our analysis of the work of scholars such as Miles et al. (1995), Hertog (2000), Miles (2005) and Tseng et al. (2011) illuminates the role of knowledge-intensive service firms as facilitators, carriers or sources-and thus co-producers-of innovations, which their client organisations can adopt within and beyond national boundaries. In their role as key contributors to the performance of clients in all sectors, these knowledge-intensive service firms facilitate the cross-national spill-over effects of innovation in service, which becomes key to responsible imovation in Asia Pacific regions. Our attention thus turns to the concept of imitation in an effort to contextualise imovation as a combination of innovation and imitation within the knowledge-based economy.

Scholars and practitioners have described imitation from a variety of perspectives. Although it is often seen as a necessity for organisations to survive in a hostile environment and something that requires a prominent strategic and operational position in organisational management (Shenkar, 2010), scholars have also referred to imitation as an embarrassing nuisance residing at the margins of business life and organisations that imitate as failing to conform to industry norms (Massini et al., 2005). Our views, however, align with the former, more positive perspective, and we adopt Krzakiewicz and Cyfert's (2016) perception of the need for business scholarship to accept imitation as a complex, intelligent and creative pursuit that requires 
rare and highly valuable capabilities. By studying sectors such as knowledge-intensive business services, where an often heterogeneous range of actors and sources openly co-produce innovations (Castaldi et al., 2013), we have learned that external partnerships often motivate those partners with more limited access to information and knowledge resources to employ imitation as a strategic choice to secure a competitive advantage.

As the knowledge-based economy continues to unfold, the concept of imovation emerges as a combination of innovation and imitation strategies (Zhou, 2009; Arvanitis \& Seliger, 2014). The literature describes organisations that seek to implement an imovation strategy with terms such as 'second movers', 'followers' and 'innovators' (Hoppe \& Lehmann-Grube, 2001; Shenkar, 2010). Scholars such as Wang and Scuotto (2012) have established a connection between imovation and innovation by referring to imovators as organisations that take inspiration from successfully innovative products and partly imitate them while offering a product or service that differs from the original while maintaining high technical specifications and/or lower production costs. Although imovation appears to assume the form of incremental innovation, it differs in that imovators make strategic alliances with innovative firms.

Scholars such as Adler et al. (2009) and Cho and Pucik (2005) have argued that organisations must simultaneously explore and exploit opportunities if they are to flourish or even survive in the current dynamic business environment. Imovators are no exception. Hobday (1995) claimed that firms perform a wide range of strategic actions, such as design copying, creative adaptation and technological leapfrogging, using exploiting knowledge from external factors. Scholars have identified these external factors as the government, competitive environment, research and development, investment funds and educational level of human resources, among others (Amara \& Landry, 2005; Knudsen, 2007; Li et al., 2010).

\section{Imovation strategy in the Asia Pacific region}

More than three decades ago, Freeman (1987) concluded that imovators exploit external knowledge related to their own network innovation system (NIS) through a knowledge exploitation approach, which enables them to improve their knowledge capacity. The relational arrangements between organisations inherent to the nature of NIS include partnerships, joint ventures, strategic alliances and networks, which have been found to be conducive to knowledge transfer and imitation (Inkpen \& Tsang, 2005; McFadyen \& Cannella, 2004; Tsai, 2001).

Asian countries exhibit significant differences not only in their levels of industrialisation and economic growth but also in their well-established traditions, cultural heritages, social practices and political and economic institutions. The region's delayed entry into the industrialised world meant that it was common practice for firms operating in its countries to imitate their counterparts from advanced economies in Europe and the United States (Hobday, 1995). Even the so-called newly industrialising economies or 'dragons' of East Asia in the 1990s (i.e. South Korea, Taiwan, Singapore and Hong Kong) had to rely on strategic alliances, original 
equipment manufacturing (OEM) or specific supply contracts to quickly acquire critical knowledge and technologies (Carney, 2008). Fundamental services provided to businesses by the region's national and local governments as well as increased collaboration between national and corporate innovation systems supported this process (Sigurdson, 2000). Sufficient evidence suggests that much of the region's success depended on the role of state mediation through science, technology and innovation policies. Universities also played an important role in this process. According to Krishna (2019), although the core knowledge and technology did not emerge from universities in the region, universities nevertheless played a pivotal part in supplying high technology skills, training and human resources to large Asian family business groups operating in various sectors. Thus, a handful of Asian firms achieved rapid growth and emerged as major players in their industries during the first decade of this century, demonstrating that their strategy was effective (Lu et al., 2008). Their disadvantageous position as latecomers, combined with unique cultural issues and management styles, led these firms to work on the acquisition of mature technologies and pursue catch-up strategies whereby entrepreneurs concentrated on imitation rather than the development of original proprietary technologies (Carney, 2008).

Economies and firms in the Asia Pacific region then continued to evolve and began achieving technological developments by engaging not only in simple imitation but also in what L. Kim and Nelson (2000) described as a process of "creative imitation'. An example involves adapting technologies to their environments and applying them to other industries. As L. Kim and Nelson (2000) explained, 'creative imitation and innovation require a highly decentralised, self-contained, strategic business unit structure; an organisational culture that nurtures creative individuals and effective small groups; effective and flexible lateral coordination across R\&D, marketing and production; and bottom-up communications to quickly identify and respond to market opportunities/threats and technological possibilities' (p. 357). These are precisely the key elements that determine a firm's ability to create and leverage knowledge capacity and, with it, succeed in the knowledge economy.

Garcia-Perez et al. (2019) outlined two main ways to understand knowledge capacity: (1) the capacity to leverage knowledge to cope with and adapt to continuous change and (2) the capacity to leverage knowledge to achieve performance. By moving from imitation to innovation, firms in the Asia Pacific region developed the capacity to detect, adapt to and cope with change. An imovation strategy nurtures an organisation-level capability that enables such firms not only to detect change and adapt to it but also to create new products and adapt existing ones to the changing needs of their actual and potential customer base, thus continuously raising the knowledge stock of the entire organisation.

\section{Theoretical framework: Dynamic capabilities}

Although the terms competencies, capacity and capability are correlated, each has a distinctive connotation (Cegarra-Navarro et al., 2020). Healey (1998) defined institutional capacity as form of special ability of a bunch of individuals to work together to solve a mutual problem. At an organisational level, competencies are defined as 
knowledge, abilities and team skills (McLagan, 1997). Two main perceptions define our approach to the study of organisational capabilities. First, Grant (1991) defined the term as the talent to handle a situation using a collection of resources. Later, Hall et al. (2011) studied organisational capabilities not merely as competencies but as collective structures, which hold organisational competencies and goals along with stakeholders' interests. Considering these views, we adopt the definition of dynamic capabilities as a firm's ability to integrate, build and reconfigure internal and external competencies to address the challenges posed by rapidly changing environments. Dynamic capabilities thus reflect an organisation's ability to achieve new and innovative forms of competitive advantage and market positions (Leonard-Barton, 1992, as cited in Teece et al. 1997, p. 516).

Helfat et al. (2007) noted that dynamic capability is the capacity of a firm to purposefully develop, expand or modify its resource base. Most literature reviews on the nature of dynamic capabilities (e.g. Wang \& Ahmed, 2007; Easterby-Smith et al., 2009; Breznik \& Hisrich, 2014) credit Teece et al. (1997) with the original definition of dynamic capabilities. Eisenhardt and Martin (2000) argued that dynamic capabilities, which comprise product development, strategic decision-making and alliancing, are identifiable, and the basic processes and activities they involve are similar across firms, although not necessarily across industries.

Some authors have approached these concepts from the perspective of firms in the Asia Pacific region. For example, studying firm performance in small and medium-sized Japanese enterprises, Isobe et al. (2008) found that firms that possess knowledge exploitation capabilities achieve better operational efficiency while those with exploration capabilities accomplish better strategic performance. However, a better understanding of the relationships between dynamic capabilities and imovation capabilities is required to provide scholars with a clearer perspective of imovation strategies and their viability and to help imovators better support the existence of entrepreneurial markets.

\section{Development of hypotheses}

Consistent with our understanding of imovation as a valuable strategy that deserves a prominent strategic and operational position in organisational management and also requires rare and highly valuable capabilities, this research sets out to explore the relationships between dynamic capabilities and imovation capabilities in firms operating in Asia Pacific countries. Scholars such as Shenkar (2010) and Krzakiewicz and Cyfert (2016) have argued that a firm's ability to manage the imovation process requires capabilities that range from the integration of business models the firm finds useful to an understanding of the firm's business context. As these scholars have explained, imovation shapes dynamic capabilities at the organisational level. In this research, we consider, in particular, the following capabilities:

- Combination and technologies capabilities. The capability of managers to systematically exploit the products of existing stocks of knowledge, such as employees' distinct knowledge skills, combined with the adoption of technol- 
ogy developments, is the key to innovation (Henderson \& Clark, 1990; Soete $\&$ Weel, 1999). Teece (2007) argued that dynamic capabilities can be operationalised as the capacity to (1) sense and shape opportunities and threats, (2) seize opportunities and (3) sustain competitiveness by improving, combining, protecting and, when necessary, reconfiguring the business enterprise's resources. A firm's dynamic capabilities emphasise the need to optimise the transfer of technology/information between and among its various units $(\mathrm{Vu}$, 2020). Unsurprisingly, in technology-intensive industries, knowledge combination has long been considered a vital combinative capability for continuous innovation (Schumpeter, 1934).

- The capability to exploit new opportunities (e.g. knowledge and technology). Scholars such as Kirzner (1973, 1997), Chandler (1990) and Teece (2007) have related the evolution of the firm not only to its ability to innovate but also to processes such as opportunity discovery, entrepreneurial alertness, dynamic capabilities and organisational learning. According to Teece (2007), sensing capability is the capacity of firms to constantly scan for, identify and explore opportunities across technologies and markets. Authors such as Shane and Venkataraman (2000) and Sarasvathy (2001) described opportunities as firms' conjectures about the most profitable ways in which economic ends can be achieved. Previous experiences and accumulated knowledge shape the opportunities that are discovered and the ways in which they are further developed into a viable business (Shane, 2000). While opportunity identification is a cognitive process, the exploitation of opportunities is dependent on action in the real world (Brink \& Holmén, 2009). The exploitation of opportunity entails a commitment to market entry, which includes activities and investments that are committed to appropriate returns from the innovation arising from the opportunity (Choi \& Shepherd, 2004). Strategic alliances facilitate the exploration and exploitation of opportunities that emerge in the business environment through knowledge combinations within the firm. Because they facilitate the integration and coordination of business processes and address some of the main challenges of the imovation process, we view strategic alliances as key to the success not only of innovators but also of imovators. For example, a lack of access to complementary and specific assets, which may include specialised manufacturing, special supplies and distribution channels, may operate as barriers to an imovation strategy. Such assets can be accessed by building alliances or finding providers that have them. We, therefore, hypothesise as follows:

- Hypothesis 1. The direct relationship between dynamic capabilities and imovation capabilities is stronger when the combination of internal capabilities and external technologies is higher.

The concept of innovation capabilities is complementary to that of dynamic capabilities (Brezinik \& Hisrich, 2014; Vu, 2020). Innovation capability, a firm's ability to mould and manage multiple capabilities (Lawson \& Samson, 2001), enables firms to integrate key capabilities and resources to successfully stimulate innovation (Vu, 2020). Our perception of innovation capabilities aligns with Wang and 
Ahmed's (2007) conceptualisation through the concepts of innovation and adaptive and absorptive capabilities.

How do innovation capabilities relate to imovation capabilities? In our view, imovators require not only the ability to imitate-i.e. imitation capabilities-but also an organisational culture that enables them to (1) sense and shape opportunities and threats, (2) seize such opportunities and (3) sustain competitiveness by improving, combining, protecting and, when necessary, reconfiguring not only the business enterprise's resources, as Teece (2007) argued, but also their products. In terms of knowledge exploration, imovators must have the ability to recognise promising solutions and then analyse and contextualise them to fully understand their distinguishing features (Krzakiewicz \& Cyfert, 2016). This ability would provide imovators with the strategic direction required to compensate for their late market entry. Imovators are more likely to succeed when they have developed the capability to integrate a product-innovation approach into their corporate strategy. We, therefore, hypothesise as follows:

Hypothesis 2. The direct relationship between dynamic capabilities and imovation capabilities is stronger when imovators significantly exploit new opportunities.

We also seek to explore the extent to which variations in strategic decision-making influence a firm's capabilities to explore new opportunities and purposefully develop, expand or modify its resource base for the sustainable exploitation of such opportunities.

Our analysis is rooted in both Eisenhardt and Martin's (2000) views of strategic decision-making as a dynamic capability for the organisation and our understanding of imovation as a process that ultimately responds to the needs of a set of stakeholders. As imovators seek imitation opportunities and work to leverage and implement them, they perform a wide range of strategic actions. One such action may involve giving a voice and sometimes a role in strategically relevant decisionmaking processes to a range of stakeholders-from employees to suppliers and even customers. This represents a multifaceted and complex challenge that requires firms to build dynamic capabilities rather than relying on ad hoc changes and adaptation efforts (Winter, 2003; Zollo et al., 2016). However, it also involves a heterogeneous set of capabilities that decision-makers must manage to develop new products. In this sense, a cross-fertilisation process occurs that includes external and internal stakeholders. As Lasytè (2019) argued, the effective involvement of stakeholders in decision-making processes helps organisations better understand and manage stakeholder needs. Giving the relevance of a firm's specific heterogeneous capabilities would enable stakeholders to contribute to the achievement of the organisation's sustainable governance and support its imovation strategies. With this in mind, we hypothesise as follows:

Hypothesis 3. The direct relationship between dynamic capabilities and imovation capabilities is stronger when the involvement of firm-specific heterogeneous capabilities is significant. 
The consensus in the literature holds that both innovation and imovation strategies and operations should be driven by significant levels of ethical behaviour in the firm. As Pandza and Ellwood (2013) explained, such ethical behaviour relies, in turn, on the firm's commitment to co-responsibility, freedom and the impact of innovations. In this context, Pandza and Ellwood (2013) also highlighted the importance of firms'virtues and emerging capabilities.

Because the social context where businesses operate strongly influences ethical agency (Weaver, 2006), we analyse emerging capabilities and virtues as a combination of virtuous traits (Treviño et al., 2003; MacIntyre, 1999) and social impact, which together determine the value of imovation capabilities for the firm and its business context. Thus, we hypothesise as follows:

\section{Hypothesis 4. Dynamic capabilities positively influence the development of responsible imovations.}

\section{Methodology}

\section{Research context}

The modern dynamic competitive market has featured a new way to compete: imovation. A combination of the most common strategies, i.e. innovation and imitation, imovation offers a sustainable and responsible way for firms to achieve a competitive advantage in the market. Firms in the Asia Pacific region have introduced the imovation strategy, which has diffused around the world. The fundamental aspect of this strategy focuses on 'catching-up' existing technologies and knowledge (Carney, 2008) to develop new products or services. Scholars have explored imovation from a macro-level perspective (Wang \& Scuotto, 2012), a meso-level position (Scuotto \& Shukla, 2018; Lee et al., 2011) and merely a theoretical view (Shenkar, 2010; Luo et al., 2012). However, the concept of sustainable and responsible innovation is gaining increasing relevance because it provides enterprises with strategic leverage. In this regard, Asia Pacific enterprises are challenging the competitive market with responsible imovation strategies that rely on the virtues and emerging capabilities of individual ethical behaviour, co-responsibility and social impact (Pandza \& Ellwood, 2013).

\section{Data collection}

Data were collected throughout the entire year of 2019. Firms were selected if they were (1) among the 21 members of Asia Pacific Economic Cooperation (APEC): Australia, Brunei, Canada, Chile, China, Hong Kong (as part of China), Indonesia, Japan, South Korea, Malaysia, Mexico, New Zealand, Papua New Guinea, Peru, Philippines, Russia, Singapore, Taiwan, Thailand, United States of America, Vietnam, (2) developing an imovation strategy and (3) using a knowledge exploitation approach (Wang \& Scuotto, 2012). Initially, we identified and 
shortlisted over 300 firms primarily based in China, Japan, India and Russia. These countries have achieved exponential growth over the last five years that has been dictated by trade, technology and investment. Recently, however, they have begun seeking sustainable development consistent with the United Nations goals (ESCAP, 2021).

All firms were categorised as medium-sized firms with over 500 employees. According to Asia Pacific Economic Cooperation, in the Asia Pacific market, the number of medium-sized firms is larger than other countries (Liu, 2008; Statista, 2021). Their turnover is up to 300 million Chinese Yuan. Because the Asia Pacific market exhibits weak technological innovation development, technology-based medium-sized firms are prone to pursue strategic alliances to secure a competitive advantage. As Scuotto and Shukla (2018) stated, imovator firms are primarily based in the IT sector; therefore, our research, selected imovative firms from this sector. Liu (2008) also remarked on the weakness in technological innovation that triggers the development of new strategic alliances. In particular, the author asserted that technological innovations are generated via the 'licensing of know-how, imitation, internal R\&D and academic (or other institution) led R\&D' (p. 48).

Only 180 firms fully completed the questionnaire, which contained nine questions. These firms' key decision-makers, such as a founder or manager, answered the questionnaire. Most respondents were men in the range of 40-50 years old. The questionnaire was administered through an online platform and translated from English to Chinese by a professional translator, consistent with Brislin's (1970) recommendations. The questionnaire's structure, which began with ancillary questions and then posed questions regarding the three key measures (i.e. dynamic capabilities, imovation capabilities and responsible imovation), aligned with Bryman's study (2008). The respondents evaluated each question by referring to a seven-point Likert scale (Joshi et al., 2015).

We conducted a pilot test to determine if the questionnaire was sufficiently clear. The 15 decision-makers who participated in the pilot test were easily able to answer all questions; therefore, no issues emerged.

We operationalised the three key measures, which are described below, according to the previous literature.

\section{Dynamic capabilities}

Consistent with Leonard-Barton (1992), we define dynamic capabilities as 'the firm's ability to integrate, build and reconfigure internal, external competencies to address rapidly changing environments. Dynamic capabilities thus reflect an organisation's ability to achieve new and innovative forms of competitive advantage and market positions' (as cited in Teece et al. 1997, p. 516). In addition, Eisenhardt and Martin (2000) categorised organisational dynamic capabilities as follows:

- product development routines

- strategic decision-making

- alliancing and acquiring resources. 


\section{Imovation capabilities}

Shenkar (2010) introduced the term imovation and described its strategic characteristics along with its capabilities. In this research, we consider the following capabilities:

- Combining internal capabilities and external technologies

- Exploiting new opportunities (e.g. knowledge and technology)

- Involving firm-specific heterogeneous capabilities.

Furthermore, according to the work of Krzakiewicz and Cyfert (2016), imovation capabilities shape dynamic capabilities. In this sense, we recognise the role of imovation capabilities as predictors of dynamic capabilities.

\section{Responsible imovation}

We adapt the concept of responsible imovation from the work of Pandza and Ellwood (2013) and Blok (2018), which defined responsible imovation based on its sustainability, social and ethical benefits, and virtuous traits and emerging capabilities (Treviño et al., 2003; MacIntyre, 1999). In this sense, we rely on the following features to identify a responsible imovation:

- virtuous traits

- sustainability

- social and ethical benefits.

On this basis, we constructed the questionnaire as follows (Table 1):

The relationships between these three measures shaped the research design (Fig. 1) that evaluates the relationship of the three aforementioned items of

Table 1 Measures and Items

\begin{tabular}{ll}
\hline Measures & Items \\
\hline Dynamic capabilities & - Employing product development routines that involve cross-functional teams \\
& with different sources of expertise \\
- Making strategic decisions about gaining and releasing resources to develop & innovations \\
& - Pursuing strategic alliances to acquire resources and develop new products \\
& into a new market \\
- Combining integrated capabilities and external technologies & - Exploiting new opportunities from external knowledge and technology \\
& - Involving firm-specific heterogeneous capabilities in innovative product \\
& development \\
- Combining virtuous traits and emerging capabilities to develop sustainable & imovations \\
- Acting strategically according to the UN Sustainable Development Goals & Providing highly significant social and ethical benefits via new products \\
\hline
\end{tabular}




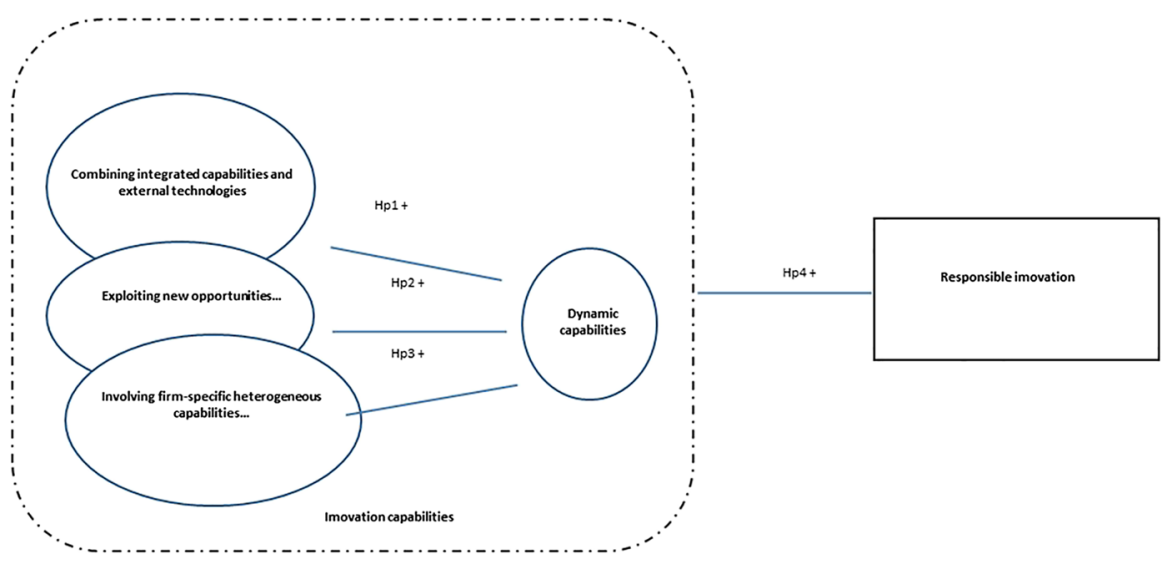

Fig. 1 Research design

imovation capabilities with dynamic capabilities. However, these dynamic capabilities were consequently correlated with responsible imovation.

\section{Data analysis}

To test the four hypotheses and, consequently, validate our research design, we employed a logistic regression analysis to study the firms' combination of internal capabilities and external technologies, ability to exploit new opportunities (e.g. knowledge and technology) and specific heterogeneous capabilities as features of imovation capabilities; we recognised these three concepts as predictors of the firms' dynamic capabilities while considering their dynamic capabilities as a response. The predictors denoted with an ' $\mathrm{X}$ ' were the independent variables, while the response denoted with a ' $Y$ ' was the dependent variable. Subsequently, the dynamic capabilities assumed the role of predictors, which we assessed in correlation with responsible imovation (as a response). The logistic regression analysis, which aligned with previous studies (Montgomery et al., 2012; Neter et al., 1996; Dayton, 1992), provides a suitable model for international business studies (Oki, 2020; Nor et al., 2017; Laskar, 2018; Mention et al., 2011).

\section{Findings}

The empirical analysis of the present research employed a principal component analysis (PCA) to evaluate the Cronbach's $\alpha$ and the composite reliability (CR) as revealed in Table 2.

We calculated the correlation between the predictors and variables using the Wald chi-statistic approach. In this case, we converted the 'responses' into a binary code $(0,1)$. Hence, we first assessed the three main characteristics of imovation capabilities against the dynamic capabilities before assessing the dynamic capabilities against responsible imovation (Peng et al.'s [2002] study also described this process). This process generated the results that appear in Table 3. 
Table 2 Cronbach's $\alpha, \mathrm{CR}$ and correlation matrix

\begin{tabular}{lllllll}
\hline & Measures & Cronbach's $\alpha$ & $\mathrm{CR}$ & (1) & (2) & (3) \\
\hline (1) & Imovation capabilities (ImovCap) & 0.801 & 0.791 & 1 & & \\
$(2)$ & Dynamic capabilities (DinCap) & 0.759 & 0.689 & $0.201^{* *}$ & 1 & \\
$(3)$ & Responsible imovation (ResImo) & 0.791 & 0.754 & 0.225 & $0.195^{* *}$ & 1 \\
\hline
\end{tabular}

Significant at the 0.00 level.

**Significant at the 0.01 level

Table 3 Wald chi-square approach

\begin{tabular}{llll}
\hline Predictors & $\begin{array}{l}\text { In the presence of } \\
\text { 'response' }\end{array}$ & $\begin{array}{l}\text { Wald } \\
\mathrm{X}^{2}\end{array}$ & $\begin{array}{l}\text { Contribution } \\
\text { of variable(s) }\end{array}$ \\
\hline StrAll & DynCap & 3.02 & Significant \\
ProdInn & DynCap & 5.22 & Significant \\
StrDecMak & DynCap & 7.10 & Significant \\
DynCap & ResImo & 5.88 & Significant \\
\hline
\end{tabular}

The present empirical analysis supports the initial four hypotheses. In particular, a value of 3.02 supports $\mathrm{H} 1$ (The direct relationship between dynamic capabilities and imovation capabilities is stronger when the combination of internal capabilities and external technologies is higher), and a value of 5.22 supports $\mathrm{H} 2$ (The direct relationship between dynamic capabilities and imovation capabilities is stronger when exploiting new opportunities is significant). $\mathrm{H} 3$ (The direct relationship between dynamic capabilities and imovation capabilities is stronger when the involvement of firm-specific heterogeneous capabilities is significant) receives support with a value of 7.10. Finally, H4 (Dynamic capabilities positively influence the development of responsible imovations) is significant and supported with a value of 5.88 .

\section{Discussion}

The purpose of this study was to identify factors that link three imovation capabilities - combining integrated internal capabilities and external technologies, the ability to exploit new opportunities (e.g. knowledge and technology) and the involvement of firm-specific heterogeneous capabilities-with dynamic capabilities and thereby to create the foundations of imovation capabilities and responsible innovation. The research model presented in the study is unique in its integration and highlights the role of responsible imovation in the possibilities of future modes of competition in the Asia Pacific region. The research design was structured to examine possible ways in which firms can achieve competitive advantage via the responsible imovation. Moreover, the model examined the fundamental aspects of the evolving strategy modes, including technology and knowledge, to develop new products and services. 


\section{Theoretical implications}

As we expected during the research design phase, our work confirms the relationship between dynamic capabilities and imovation capabilities and thus expands upon previous studies (Krzakiewicz \& Cyfert, 2016; Eisenhardt \& Martin, 2000; Shenkar, 2010). In this sense, our results highlight the significance of both capabilities to develop responsible imovation in the Asia Pacific market. These capabilities connect the internal and external environment of a firm with the aim of creating new knowledge. For instance, dynamic capabilities entail seizing, shaping and sensing opportunities that can trigger responsible imovation. In turn, imovators can avoid utilising simplistic models to analyse complex real-world phenomena. Rather, they can diagnose complex problems by isolating independent components without losing sight of their relationship to the internal architecture of the whole.

The results of our study largely support the hypotheses we proposed at the design stage. First, we found support for H1, which held that the direct relationship between dynamic capabilities and imovation capabilities is stronger when the combination of capabilities and technologies is higher. This hypothesis highlights the various possibilities for cooperation among firms, even among firms that are considered close competitors; in such highly competitive situations, in fact, our results suggest that cooperation and competition can coexist via coopetition strategies (Mention, 2011). Testing our second hypothesis ( $\mathrm{H} 2)$, which held that the direct relationship between dynamic capabilities and imovation capabilities is stronger when exploiting new opportunities is significant, produced a similar result. Imitation does not contradict but instead complements innovation, especially in the case of product innovation. A firm's overall strategy should thus incorporate imitative activity while also engaging in the continuous observation of the external environment, thus exploiting new opportunities and reinforcing the firm's involvement in product innovation. These observations can also be correlated with the assumption that the direct relationship between dynamic capabilities and imovation capabilities is stronger when firm-specific heterogeneous capabilities are significant (H3). Imovators are supported by a diverse range of capabilities that are managed at the strategic decision-making level. This level is focused on innovating and seeking a balance between innovation and imitation. Firms are increasingly abandoning the identification of imitation as a disorderly act outside the horizon of crucial business activities. In fact, imitation and innovation are not mutually exclusive. Rather, they create an integrated system associated with complementary features, which means that imitation should be seen not as an obstacle but as a stimulator of a properly designed and organised innovation process. When strategic activities are focused on creating inter-organisational networks as strategic alliances, firms can move beyond imitating or improving value to engage, instead, in value creation.

With this scenario, exploiting firms' specific heterogeneous capabilities become crucial to develop new innovations and achieve sustainable goals. This supports the logic behind the concept of responsible imovation, which hypothesised, in $\mathrm{H} 4$, that dynamic capabilities positively influence the development of responsible imovation strategies. The literature on innovation strategies is vibrant; in particular, interest in the issue of both strategy and competition through implemented innovations has 
grown steadily for several decades (Kalisz \& Aluchna, 2012; Di Vaio et al., 2021). Recently, these efforts have been characterised by an increasing interest in sustainability. Therefore, responsible imovation is understood as a process that relies on the virtues and emerging capabilities of individual ethical behaviour, co-responsibility and social impact (Pandza \& Ellwood, 2013). Moreover, responsible imovation introduces a new and sustainable way of merging innovation and imitation and enhancing firm competitiveness.

Overall, our research model highlights imovation capabilities as predictors of dynamic capabilities, which are formed via product innovation, strategic decisionmaking and alliancing (Eisenhardt \& Martin, 2000) in the Asia Pacific market. In this way, our work supports and expands upon previous studies on imovation (such as Wang \& Scuotto, 2012; Scuotto \& Shukla, 2018; Lee et al., 2011; Shenkar, 2010; Luo et al., 2012) by offering quantitative research that examines organisational capabilities as imovative and dynamic ones.

\section{Managerial implications}

Our research model explains the significance of dynamic capabilities in firms' efforts to develop innovation and imitation strategies in the Asia Pacific regions, which was the main scope of our analysis. The Asia Pacific region remains at the stage of rapid acceleration. In the international struggle for competitive market shares, the region is relatively young and, therefore, innovative by definition. Consequently, it is essential for firms there to apply innovation. Market players must innovate to maintain their market shares and search for niches, which are linked with creating innovative products and new forms of imitation strategies. Competitive advantage in the Asia Pacific region is volatile, and firms must constantly evolve to maintain it. To meet this challenge, firms often engage (intentionally or unintentionally) in imitation, the pace of which is driven by continuous innovation at the strategic level.

Imitation can take many forms. Some firms copy other firms' behaviour patterns without making any changes at all, while others adopt existing patterns to new conditions or make visible improvements. Similarly, some firms analyse the characteristics of the models they acquire, while others are content simply to repeat these models' most visible features. The dangers of imitation lead most firms to focus their efforts on constructing barriers to prevent the potential imitation of innovations, but they fail to consider the benefits they might gain by imitating others.

Most managers - even those who have already taken ideas and concepts from competitors-react negatively when faced with the suggestion that their firms engage in imitation. However, even managers who recognise the desirability and legitimacy of imitation admit that their firms lack a systematic and methodical approach for exploiting the potential of imitation. Some firms attempt to copy a specific business component to achieve the sustainable competitive advantage they seek, while others seek to copy entire business models. Our study demonstrates conclusively that imitation can take many forms. In addition, analyses of imitative firms' operations reveal that many of imitators are also innovators. While the drive to imitate has always existed, the last decade has witnessed a tremendous increase 
in firms' ability to do so (Bonabeau, 2004). From a managerial perspective, innovations and imovations strategies are the key components to business survival, growth and further development. From a strategic perspective, the appearance of imitators is always apparent, and due to the compression of time and rapid access to information, the pace of imitation is faster than ever (Lee \& Zhou, 2012).

The essential managerial implications highlight the fact that firms' imovation processes and their success often follow their most significant competitors. If a competitor has designed and planned the strategic moves correctly, the resulting imovation strategy may work perfectly. However, imovative firms can also correct their competitor's mistakes, especially when space exists in the market for both firms- the competitor (creator) and the imovator. Unfortunately, sometimes the competitor has no clear idea about its strategy. In such situations, the competitor's short-term success may simply result from favourable circumstances in the external environment, and other businesses' imitation (and, simultaneously, their attempts to imovate) can be catastrophic. Fundamental changes in the short-term strategy approach enable the most effective imovators (based on their ability to imitate rapidly) to dominate the creators of an original product or service and gain a competitive advantage in the market. This approach underscores the constant need to bolster innovation to extend the exploitation phase of competitive advantage and continuously reconfigure resources to defend a firm's market position (McGrath, 2013). Perhaps, nowadays, the effectiveness of strategy requires skillful imitation.

For managers, imovation entails many advantages. It can accelerate organisational learning, advance social cohesion and boost strategic inspiration and aspiration at the corporate level. However, the essential virtue of imovation in the Asian Pacific region is the possibility of making rational economic choices, innovating the business models and achieving sustainable competitive advantage. Interestingly, although the imovation strategy can begin with simple imitation, the application of continuous innovation by imovative managers can lead to victory in competitive battle and the creation of new market space, new demand and new market segments. Such a configuration in short-term strategic planning makes the competition irrelevant. Imovation should thus be seen as a kind of action strategy coordinated with innovative projects and necessary for the concentration and effective use of innovative capabilities. The alignment of imitation processes with innovationconfirms that from the managerial perspective, the most significant benefits of productivity growth are associated not so much with the original innovations but with the improvements that follow from them. This combination of imovation practices has the potential to provide customers with not only an improved but also a much less expensive product (Bourkha, 2019). Imovators know how to create and effectively use the specific product features associated with imitation.

This relationship of innovation and imitation can be voluntary as firms react with a double paradoxical intention, imitating and innovating simultaneously to create the source of differentiation. The managerial implications of the imovation strategy appear quite promising for advancing strategic (although not always competitive) moves. The use of imovative moves is rooted strongly in the science of strategy, which has emerged over the last few decades. Although a deeper understanding and the possibility of creating future paths towards imovative consequences remain at 
the early stages of managerial exploration, they are slowly emerging as an essential component of strategic choices.

\section{Conclusions, research limitations and future research}

The data on strategies for combining innovation and imovation presented in our research project rely on the information presented is solely an analysis that is framed on the responses obtained from the respondents (in the Asia Pacific region) during the survey. Although we do not claim infallibility in presenting the phenomena, we conducted our study using the adopted methodology to allow other researchers dealing with the same issues to arrive at similar conclusions.

Imitation involves copying, reconstructing or reproducing an innovation or new solution. The object of copying can be a product, service, process, procedure or business model. Imitation can follow the 'same' principle as the original, or it can entail some modification or adaptation of the original. Imovation can also change the nature of the original and thus entail not exact replication but rather the adoption of ideas. Finally, it can create a link between intuitive imitation and complete copying. Responsible imovation should be seen as a kind of action strategy coordinated with innovative undertakings and necessary for the concentration and effective use of innovative, dynamic capabilities. While innovators incur substantial financial expenses to set new directions for development, responsible imovators follow them, reducing not only their involvement in $\mathrm{R} \& \mathrm{D}$ and other areas but also the cost structure of their business model, especially on the level of the value proposition. However, a substantial difference exists between imitating value and improving value (Kim \& Mauborgne, 2015). Responsible imovators thus engage in value improvement ('creative imitation'), integrating copied elements with innovative approaches and knowledge of situational conditions.

At present, effective strategies require skillful, responsible imovation. Opportunities for imitation constantly arise. Even if innovators block the imitation efforts of firms with limited strategic capabilities, the latter can succeed by offering lower prices and gradually developing their capabilities until they can eventually provide a comparable solution on their own or with an alliance partner. A significant problem, however, is these firms lack of awareness regarding what can and should be imitated and where the object of imitation is located. Responsible imovation is associated with substantial costs, although these are much lower than the costs incurred for innovation. Like the benefits of responsible imovation, the costs also depend on the planned imitative activities of other firms, their dynamic imitative capabilities and, finally, anticipated reactions of customers.

Among the limitations of the current study is undoubtedly the limitation of its scope to the Asia Pacific region. Although the results are unambiguous and indicate the growing role of responsible imovation as a long-term strategy, they are not necessarily generalisable to firms operating in other markets. Our study identifies the responsible imovation phenomena that occur among firms in the 
Asia Pacific region, the varieties of these phenomena as well as their relationships and links to dynamic capabilities, product innovation and strategic alliance; however, it does not provide information on the frequency of these phenomena's occurrence. A study designed to measure the percentage of responsible imovation strategies and their combination with innovation might allow the analysis of imovation as a leading strategy.

This study's objectives and research questions also suggest additional questions for future enquiry. The phenomenon of responsible imovation opens the way to further research on the taxonomy of imitative strategies and the understanding of responsible imovation. At the same time, it encourages research on the construction of a new definition of responsible imovation based on an analysis of the relevant literature and an examination of the relationships between the various elements of its purpose. Our study of responsible imovation highlights the need for further investigation of phenomena specific to competitive processes, including new phenomena thus far neglected in the literature, such as imovation co-created in strategic alliances or at the level of business coopetition.

The characteristics of responsible imovation and the combination of imitation and innovation open the way to optimisation studies, which seek, first, to identify the ideal long-term strategy under the given conditions and, then, to coordinate its operation to achieve competitive advantage through imovation. Although we have achieved our study's overarching goal and confirmed our research hypotheses, specific issues relating to responsible imovation require deeper analysis. Indeed, the limitations of the published concepts in the relevant literature, the research results presented in this paper and the current state of knowledge demand additional cognitive efforts in the outlined directions.

Increasing — and increasingly rapid - access to knowledge and information has facilitated the emergence of imitators and significantly accelerated the process of responsible imitation, which often enables imitators to overtake their competitors. The development of technology continues to create ever wider possibilities of imitation, and the increasing compression of time enables their more frequent occurrence. Ultimately, responsible imovation is becoming more effective, more accessible and more rapid as responsible imovations combined with product-level innovations and core dynamic capabilities place firms on the path to faster growth and a more sustainable competitive advantage.

Open Access This article is licensed under a Creative Commons Attribution 4.0 International License, which permits use, sharing, adaptation, distribution and reproduction in any medium or format, as long as you give appropriate credit to the original author(s) and the source, provide a link to the Creative Commons licence, and indicate if changes were made. The images or other third party material in this article are included in the article's Creative Commons licence, unless indicated otherwise in a credit line to the material. If material is not included in the article's Creative Commons licence and your intended use is not permitted by statutory regulation or exceeds the permitted use, you will need to obtain permission directly from the copyright holder. To view a copy of this licence, visit http://creativecommons.org/licen ses/by/4.0/. 


\section{References}

Adler, P., Benner, M., Brunner, D., MacDuffie, J. P., Osono, E., Staats, B., Takeuchi, H., Tushman, M., $\&$ Winter, S. 2009. Perspectives on the productivity dilemma. Journal of Operations Management, 27(2): 99-113.

Barney, J. 1991. Firm resources and sustained competitive advantage. Journal of Management, 17(1). https://doi.org/10.1177/014920639101700108.

Blok, V. 2018. Philosophy of innovation: A research agenda. Philosophy of Management, 17(1): 1-5.

Bloodgood, J. M. 2019. Knowledge acquisition and firm competitiveness: The role of complements and knowledge source. Journal of Knowledge Management, 23(1): 46-66.

Bonabeau, E. (2004), The peris of the imitation age. Harvard Business Review, ID: R0406B, 2004.

Bonsu, S., \& Kuofie, M. 2019. Innovation: Discovering untapped customers for global development. Journal of Economic Development, Management, IT, Finance, and Marketing, 11(1): 1-11.

Bourkha, B. (2019). L'imovation, vers un nouvel objet de recherche en management stratégique, XXVIIIe Conférence Internationale de Management Stratégique, AIMS Association Internationale of Management Stratégique

Brink, J., \& Holmén, M. 2009. Capabilities and radical changes of the business models of new bioscience firms. Creativity and Innovation Management, 18(2): 109-120.

Brislin, R. W. 1970. Back-translation for cross-cultural research. Journal of Cross-Cultural Psychology, 1(3): $185-216$

Bryman, A. 2008. Of methods and methodology. Qualitative Research in Organisations and Management: An International Journal, 3(2): 159-168.

Castaldi, C., Faber, J., \& Kishna, M. J. 2013. Co-innovation by KIBS in environmental services: A knowledge-based perspective. International Journal of Innovation Management, 17(05): 1350017-1350020.

Carney, M. 2008. The many futures of Asian business groups. Asia Pacific Journal of Management, 25(4): 595-613.

Chandler, A. (1990). Scale and scope. The dynamics of industrial capitalism. The Belknap Press of Harvard University Press

Cho, H., \& Pucik, V. 2005. Relationship between innovativeness, quality, growth, profitability and market value. Strategic Management Journal, 26: 555-575.

Choi, Y., \& Shepherd, D. 2004. 'Entrepreneurs' decisions to exploit opportunities. Journal of Management, 30: 377-395.

Coleman, L., \& Casselman, R. M. 2016. Optimising decisions using knowledge risk strategy. Journal of Knowledge Management, 20(5). https://doi.org/10.1108/JKM-11-2015-0465.

Dayton, C. M. 1992. Logistic regression analysis. Stat: 474-574.

Di Vaio, A., Palladino, R., Pezzi, A., \& Kalisz, D. E. 2021. The role of digital innovation in knowledge management systems: A systematic literature review. Journal of Business Research, 123: 220-231.

Doloreux, D., \& Shearmur, R. 2013. Innovation strategies: Are knowledge intensive business services just another source of information? Industry and Innovation, 20(8): 719-738.

Eisenhardt, K. M., \& Martin, J. A. 2000. Dynamic capabilities: What are they? Strategic Management Journal, 21(10-11): 1105-1121.

ESCAP (2021). Asia-Pacific Trade and Investment Report 2021: Accelerating Climate-Smart Trade and Investment for Sustainable Development. Retrieved on 02 November 21. Available at https://www. unescap.org/kp/APTIR2021\#.

Frenz, M. \& Lambert, R. (2012). Mixed modes of innovation: An empiric approach to capturing firms' innovation behaviour. OECD Science, Technology and Industry Working Papers, 2012(06), OECD Publishing.

Genc, E., Dayan, M., \& Genc, O. F. 2019. The impact of SME internationalisation on innovation: The mediating role of market and entrepreneurial orientation. Industrial Marketing Management, 82: 253-264.

Grant, R. M. 1991. The resource-based theory of competitive advantage: Implications for strategy formulation. California Management Review, 33(3): 114-135.

Hall, J. H., Sarkani, S., \& Mazzuchi, T. A. 2011. Impacts of organisational capabilities in information security. Information Management \& Computer Security, 19(3): 155-176.

Healey, P. 1998. Building institutional capacity through collaborative approaches to urban planning. Environment and Planning A, 30(9): 1531-1546. 
Henderson, R. M., \& Clark, K. B. 1990. Generational innovation: The reconfiguration of existing systems and the failure of established firms. Administrative Sciences Quarterly, 35: 9-30.

Hertog, P. D. 2000. Knowledge-intensive business services as co-producers of innovation. International Journal of Innovation Management, 4(04): 491-528.

Hobday, M. 1995. East Asian latecomer firms: Learning the technology of electronics. World Development, 23: 1171-1193.

Inkpen, A. C., \& Tsang, E. W. K. 2005. Social capital, networks, and knowledge transfer. Academy of Management Review, 30: 146-165.

Isobe, T., Makino, S., \& Montgomery, D. B. 2008. Technological capabilities and firm performance: The case of small manufacturing firms in Japan. Asia Pacific Journal of Management, 25(3): 413.

Jahanshahi, A. A., \& Brem, A. 2020. Entrepreneurs in post-sanctions Iran: Innovation or imitation under conditions of perceived environmental uncertainty? Asia Pacific Journal of Management, 37(2): $531-551$.

Jenkins, M. 2014. Innovate or imitate? The role of collective beliefs in competences in competing firms. Long Range Planning, 47(4): 173-185.

Joshi, A., Kale, S., Chandel, S., \& Pal, D. K. 2015. Likert scale: Explored and explained. Current Journal of Applied Science and Technology: 396-403.

Kalisz, D., \& Aluchna, M. 2012. Research and innovations redefined. Perspectives on European Union initiatives and strategic choices on horizon 2020. European Integration Studies, 6: 140-149.

Kim, L., \& Nelson, R. R. (Eds.) 2000. Technology, learning, and innovation: Experiences of newly industrialising economies. Cambridge University Press.

Kim, W. C., \& Mauborgne, R. 2015. Expanded edition of Blue Ocean strategy: How to create uncontested market space and make the competition irrelevant. Harvard Business Review Publishing.

Kirzner, I. 1973. Competition and entrepreneurship. Chicago University Press.

Kirzner, I. 1997. Entrepreneurial discovery and the competitive market process: An Austrian approach. Journal of Economic Literature, 35: 60-85.

Krishna, V. V. 2019. Universities in the national innovation systems: Emerging innovation landscapes in Asia-Pacific. Journal of Open Innovation: Technology, Market, and Complexity, 5(3): 43.

Krzakiewicz, K., \& Cyfert, S. 2016. Imovation in shaping dynamic capabilities of organisations. Management, 20(2): 8-22.

Laskar, N. (2018). Impact of corporate sustainability reporting on firm performance: An empirical examination in Asia. Journal of Asia Business Studies, 12(4).

Lasytė, G. 2019. The role of stakeholders in corporate governance: Theoretical approach. Contemporary Research on Organization Management and Administration, 7(1): 74-85.

Liu, X. (2008), SME development in China: A policy perspective on SME industrial clustering. In H. Lim (Ed.), SME in Asia and globalization, ERIA Research Project Report 2007-5, 37-68. Available at: http://www.eria.org/SME\%20Development\%20in\%20China_A\%20Policy\%20Perspective\% 20on\%20SME\%20Industrial\%20Clustering.pdf

Lu, Y., Tsang, E. W., \& Peng, M. W. 2008. Knowledge management and innovation strategy in the Asia Pacific: Toward an institution-based view. Asia Pacific Journal of Management, 25: 361-374.

Luo, Y., Sun, J., \& Wang, S. L. 2011. Emerging economy copycats: Capability, environment, and strategy. Academy of Management Perspectives, 25(2): 37-56.

MacIntyre, A. C. 1999. Dependent rational animals: Why human beings need the virtues, vol. 20. Open Court Publishing.

McFadyen, M., \& Cannella Jr., A. 2004. Social capital and knowledge creation: Diminishing returns of the number and strength of exchange relationships. Academy of Management Journal, 47: 735-746.

McGrath, R. 2013. The end of competitive advantage: How to keep your strategy moving as fast as your business. Harvard Business Review Press.

McLagan, P. A. 1997. Competencies: The next generation. Training \& Development, 51(5): 40-48.

Mention, A. L. 2011. Cooperation and coopetition as open innovation practices in the service sector: Which influence on innovation novelty? Technovation, 31(1): 44-53.

Montgomery, D. C., Peck, E. A., \& Vining, G. G. 2012. Introduction to linear regression analysis, vol. 821. John Wiley \& Sons.

Miles, I. 2005. Knowledge intensive business services: Prospects and policies. Foresight, 7(6): 39-63. https://doi.org/10.1108/14636680510630939.

Miles, I., Kastrinos, N., Bilderbeek, R., Hertog, P. D., Flanagan, K., Huntink, W., \& Bouman, M. (1995). Knowledge-intensive business services: Users, carriers and sources of innovation. European Innovation Monitoring System (EIMS) Reports, European Commission, Brussels, Belgium. 
Retrieved on 01.11.21 from https://www.research.manchester.ac.uk/portal/files/32800224/FULL_ TEXT.PDF

Narver, J. C., \& Slater, S. F. 1990. The effect of a market orientation on business profitability. Journal of Marketing, 54(4): 20-35.

Neter, J., Kutner, M. H., Nachtsheim, C. J. \& Wasserman, W. (1996). Applied linear statistical models (Vol. 4, p. 318). Irwin

Nor, N. G. M., Bhuiyan, A. B., Said, J. \& Alam, S. S. (2017). Innovation barriers and risks for food processing SMEs in Malaysia: A logistic regression analysis. Geografia-Malaysian Journal of Society and Space, 12(2).

Oki, K. 2020. Factory performance and decision-making authority between headquarters, expatriates, and local employees in Japanese MNCs in Southeast Asia. Asian Business \& Management, 19(1): $86-117$.

Pandza, K., \& Ellwood, P. 2013. Strategic and ethical foundations for responsible innovation. Research Policy, 42(5): 1112-1125.

Pawlowsky, P., Pflugfelder, N. S., \& Wagner, M. H. 2021. The ISO 30401 knowledge management systems standard: A new framework for value creation and research? Journal of Intellectual Capital, 22(3). https://doi.org/10.1108/JIC-07-2020-0256.

Peng, C. Y. J., Lee, K. L., \& Ingersoll, G. M. 2002. An introduction to logistic regression analysis and reporting. The Journal of Educational Research, 96(1): 3-14.

Pérez-Luño, A., Cabrera, R. V., \& Wiklund, J. 2007. Innovation and imitation as sources of sustainable competitive advantage. Management Research: Journal of the Iberoamerican Academy of Management, 5(2): 71-82.

Ramoglou, S., Gartner, W. B., \& Tsang, E. W. 2020. 'Who is an entrepreneur?' Is (still) the wrong question. Journal of Business Venturing Insights, 13: e00168.

Sarasvathy, S. 2001. Causation and effectuation: Toward a theoretical shift from economic inevitability to entrepreneurial contingency. Academy of Management Review, 26: 243-288.

Schumpeter, J. A. 1934. The theory of economic development. Harvard University Press.

Scuotto, V., \& Shukla, S. 2018. Being innovator or 'imovator': Current dilemma? Journal of the Knowledge Economy, 9(1): 212-227.

Shane, S., \& Venkataraman, S. 2000. The promise of entrepreneurship as a field of research. Academy of Management Review, 25: 217-226.

Shenkar, O. 2010. Copycats: How smart firms use imitation to gain a strategic edge. Strategic Direction., 26(10): $3-5$.

Sigurdson, J. 2000. Knowledge creation and innovation in geographically dispersed organisations. Asia Pacific Journal of Management, 17: 297-330.

Singh, S. K., Chen, J., Del Giudice, M., \& El-Kassar, A. N. 2019. Environmental ethics, environmental performance, and competitive advantage: Role of environmental training. Technological Forecasting and Social Change, 146: 203-211.

Singh, S. K., Del Giudice, M., Chierici, R., \& Graziano, D. 2020. Green innovation and environmental performance: The role of green transformational leadership and green human resource management. Technological Forecasting and Social Change, 150: 119762.

Soete, L. \& Weel, B. T. (1999). Innovation, knowledge creation and technology policy in Europe. Unpublished paper. Maastricht University, Maastricht, The Netherlands.

Stankevice, I. 2015. Innovation strategies as outcomes of KM practices and antecedents of firm performance: Evidence from European economies. Electronic Journal of Knowledge Management, 13(1): 62.

Statista (2021), retrieved on 30.10.21 from https://www.statista.com/statistics/1261598/global-smes-by-region/

Su, Y. S., Tsang, E. W., \& Peng, M. W. 2009. How do internal capabilities and external partnerships affect innovativeness? Asia Pacific Journal of Management, 26(2): 309-331.

Tamzini, K., Ayed, T. L., \& Boulanouar, A. 2016. How to measure tacit knowledge? The V.R.I.N model's method. Knowledge Management, 16(3). https://doi.org/10.18848/2327-7998/CGP/V16I03/1-17.

Teece, D. J. 2007. Explicating dynamic capabilities: The nature and microfoundations of (sustainable) enterprise performance. Strategic Management Journal, 28(13): 1319-1350.

Treviño, L. K., Brown, M., \& Hartman, L. P. 2003. A qualitative investigation of perceived executive ethical leadership: Perceptions from inside and outside the executive suite. Human Relations, 56(1): $5-37$. 
Tsai, W. 2001. Knowledge transfer in interorganizational networks: Effects of network position and absorptive capacity on business unit innovation and performance. Academy of Management Journal, 44: 996-1004.

Tseng, C., Chang Pai, D., \& Hung, C. 2011. Knowledge absorptive capacity and innovation performance in KIBS. Journal of Knowledge Management, 15(6): 971-983.

Ulhøi, J. P. 2012. Modes and orders of market entry: Revisiting innovation and imitation strategies. Technology Analysis \& Strategic Management, 24(1): 37-50.

Vu, H. M. 2020. A review of dynamic capabilities, innovation capabilities, entrepreneurial capabilities and their consequences. The Journal of Asian Finance, Economics and Business (JAFEB), 7(8): 485-494.

Wanasika, I., \& Conner, S. L. 2011. When is imitation the best strategy? Journal of Strategic Innovation and Sustainability, 7(2): 79-93.

Wang, T., Zhang, T., \& Shou, Z. 2019. The double-edged sword effect of political ties on performance in emerging markets: The mediation of innovation capability and legitimacy. Asia Pacific Journal of Management: $1-28$.

Weaver, G. R. 2006. Virtue in organisations: Moral identity as a foundation for moral agency. Organisation Studies, 27(3): 341-368.

Williamson, P. J., \& Yin, E. 2014. Accelerated innovation: The new challenge from China. MIT Sloan Management Review, 55(4): 27.

Winter, S. G. 2003. Understanding dynamic capabilities. Strategic Management Journal, 24(10): 991-995.

Wu, J., Harrigan, K. R., Ang, S. H., \& Wu, Z. 2019. The impact of imitation strategy and R\&D resources on incremental and radical innovation: Evidence from Chinese manufacturing firms. The Journal of Technology Transfer, 44(1): 210-230.

Wu, J., Zhang, X., Zhuo, S., Meyer, M., Li, B., \& Yan, H. 2020. The imitation-innovation link, external knowledge search and China's innovation system. Journal of Intellectual Capital, 21(5): 727-752.

Yi, J., Hong, J., Cchung Hsu, W., \& Wang, C. 2017. The role of state ownership and institutions in the innovation performance of emerging market enterprises: Evidence from China. Technovation, 62: $4-13$.

Zhao, S., Tan, H., Papanastassiou, M., \& Harzing, A. W. 2020. The internationalisation of innovation towards the south: A historical case study of a global pharmaceutical corporation in China (19932017). Asia Pacific Journal of Management, 37(2): 553-585.

Zhu, Y., Wittmann, X., \& Peng, M. W. 2012. Institution-based barriers to innovation in SMEs in China. Asia Pacific Journal of Management, 29(4): 1131-1142.

Zollo, M., Bettinazzi, E. L., Neumann, K., \& Snoeren, P. 2016. Toward a comprehensive model of organisational evolution: Dynamic capabilities for innovation and adaptation of the enterprise model. Global Strategy Journal, 6(3): 225-244.

Zou, T., Ertug, G., \& George, G. 2018. The capacity to innovate: A meta-analysis of absorptive capacity. Innovation, 20(2): 87-121.

Publisher's note Springer Nature remains neutral with regard to jurisdictional claims in published maps and institutional affiliations.

Veronica Scuotto (PhD, FHEA, MBA, BA-Honour), Associate Professor at the Department of Economics, Management, and Institutions at the University of Federico II. Previously, after working at the University of the West of Scotland (UK) and then at the Pôle Universitaire Léonard de Vinci in Paris (France) as an Associate Professor in Entrepreneurship and Innovation, she joined the University of Turin (Italy). She has got the Italian National qualification as Full Professor in 2020. She received a PhD in marketing and enterprise management from Milan Bicocca University (Italy). She has been invited as a guest speaker to GfWM Knowledge Camp; World Young Forum; PDW at the AoM Conference, among others. In 2018, she organized a conference in "Cognitive perspective in Entrepreneurship research" in joint with IPAG university in Paris. Her research interests are focused on SMEs, entrepreneurship, knowledge management, and digital technologies. Her work has been featured in several peer to peer journals such as Journal of Product Innovation Management (4*); Journal of World Business (4*), Journal of Organizational Behaviour (4*), Journal of Business Research (3*), Production Planning \& Control 
(3*), Technological Forecasting and Social Change (3*), International Marketing Review (3*), IEEE Transactions on Engineering Management ( $3 *$, among others. She has authored two books. Veronica is the Editorial Assistant of Journal of Intellectual Capital, and an Editorial Board member of the Journal of Knowledge Management. Furthermore, in 2020, Veronica's work on JOB has been awarded as the tenth most cited article. She also received two awards as the best Paper of the EuroMedISIMA track "New Challenges in Open Innovation" in 2016 and the "best-commended paper" in 2017 at the annual EuroMed Academy of Business (EMAB) conference. In 2018 she was recognized by International Council for Small Business (ICSB) as a global partner of excellence.

Alexeis Garcia-Perez , Professor of Management Information Systems at Coventry University (UK) and Visiting Research Scholar at Georgetown University (USA). A PhD in Information Systems and Knowledge Management from Cranfield University (UK) complemented his original background in Computer Science, enabling an interdisciplinary perspective of Management Information Systems research and practice. Alexeis has published widely on the subject of knowledge management and its applications in business and society, including three Emerald books co-authored with international scholars. He serves as an advisor on a number of national and international bodies focused on knowledge management, cybersecurity and digital resilience in the public and private sectors.

David E. Kalisz , Associate Professor at the Paris School of Business Doctor of economics in the discipline of management sciences. Associate Professor and Head of Management Department at Paris School of Business (France). Expert in Futures Studies Strategic Foresight and scenario Planning. Certified Foresight Practitioner (IFTF) member of Association of Professional Futurists and International Institute of Forecasters. He teaches Megatrends and Understanding Future and also courses designed to deeper test and explore the long-term impact on industries and society.

Amandeep Dhir (DSc, PhD), Professor of Research Methods at University of Agder, Norway. He is also a visiting professor at Norwegian School of Hotel Management, University of Stavanger, Norway. His research appears in the Technology Forecasting and Social Change, Journal of Business Research, Tourism Management, Internet Research, Journal of Retailing and Consumer Services, International Journal of Information Management, Computers in Human Behaviour, Computers in Industry, International Journal of Hospitality Management, Journal of Cleaner Production, Food quality and preferences, Appetite, Information Technology \& People, Australasian Marketing Journal, Enterprise Information Systems among others. 


\title{
Authors and Affiliations
}

\section{Veronica Scuotto ${ }^{1,2}$ (D) Alexeis Garcia-Perez ${ }^{3}$. David E. Kalisz ${ }^{4}$. Amandeep Dhir ${ }^{5,6,7}$}

\author{
Alexeis Garcia-Perez \\ alexeis.garcia-perez@ coventry.ac.uk \\ David E. Kalisz \\ d.kalisz1@psbedu.paris \\ Amandeep Dhir \\ amandeep.dhir@uia.no \\ 1 Leonard de Vinci, Pole universitaire, Research center, La Défense, 92916 Paris, France \\ 2 Department of Economics, Management, and Institutions, University of Naples Federico II, \\ Naples, Italy \\ 3 Centre for Business in Society, Coventry University, Coventry, UK \\ 4 Paris School of Business, Paris, France \\ 5 Department of Management, School of Business \& Law, University of Agder, Kristiansand, \\ Norway \\ 6 The Norwegian School of Hotel Management, Faculty of Social Sciences, Stavanger, Norway \\ 7 Optentia Research Focus Area, North-West University, Vanderbijlpark, South Africa
}

